\title{
Assessment of Gastroprotective Potential of Delonix regia (Boj Ex Hook) Raf against Ethanol and Cold Restrain Stress-Induced Ulcer in Rats
}

\author{
Neetu Sachan ${ }^{1 *}$, Phool Chandra ${ }^{1}$ and Dilipkumar $\mathrm{Pal}^{2}$ \\ ${ }^{1}$ School of Pharmaceutical Sciences, IFTM University, Lodhipur Rajput, Moradabad-244 102, Uttar Pradesh, India, ${ }^{2}$ Institute of \\ Pharmaceutical Sciences, Guru Ghasidas Viswavidyalaya, Koni, Bilaspur-495 009, Chhattisgarh, India
}

*For correspondence: Email: neetuphool@gmail.com; Tel: +91 591 2360022; Fax: +91 5912550214

Received: 16 October 2014

Revised accepted: 26 April 2015

\begin{abstract}
Purpose: To assess the gastroprotective potential of the stem bark ethanol extract of Delonix regia (EDR) on ethanol and cold restrain stress-induced ulcer in experimental rats.

Methods: EDR (100, 200 and $400 \mathrm{mg} / \mathrm{kg}$ doses, orally) was evaluated on ethanol and cold restrain stress-induced ulcer in experimental rats. In ethanol induced ulcer model, ulcer index, percent protection, reduced glutathione (GSH), malondialdehyde (MDA), superoxide dismutase (SOD), catalase (CAT), myeloperoxidase (MPO), cytokines and nitric oxide (NO) levels in stomach tissue were evaluated. In the cold restrain stress model, ulcer index, percent protection, and GSH levels were evaluated. 2,2-Diphenyl-1-picryl hydrazyl (DPPH) radical scavenging assay of EDR was also performed. Results: EDR caused a significant $(p<0.05-0.001)$ decreased ulcer index in ethanol $(61.33-76.00 \%)$ and cold restrain stress $(47.34-84.28 \%)$ models. The EDR caused a significant $(p<0.05-0.001)$ increase in SOD (0.20 - $0.27 \mathrm{U} / \mathrm{mg}$ protein, CAT (200 - $270 \mu$ mole $\mathrm{H}_{2} \mathrm{O}_{2} / \mathrm{mg}$ of protein/minute), GSH (1.63 - $1.17 \mu \mathrm{g} / \mathrm{mg}$ protein) and reduction in nitric oxide (NO) level, pro-inflammatory cytokine (TNF- $\alpha$ and IL-6) levels and inhibition in neutrophil accumulation $(p<0.001)$ in ethanol-induced model. EDR exhibited significant antioxidant activity with $I C_{50}$ value of $45.23 \pm 3.23 \mu \mathrm{g} / \mathrm{m} /$.

Conclusion: The results suggest that EDR has gastroprotective effect in the two ulcer models and this may be due to its antioxidant effect.
\end{abstract}

Keywords: Delonix regia, Fabaceae, Ethanol-induced ulcer, Cold restrain stress-induced ulcer, Gastroprotective, Pro-inflammatory cytokines

Tropical Journal of Pharmaceutical Research is indexed by Science Citation Index (SciSearch), Scopus, International Pharmaceutical Abstract, Chemical Abstracts, Embase, Index Copernicus, EBSCO, African Index Medicus, JournalSeek, Journal Citation Reports/Science Edition, Directory of Open Access Journals (DOAJ), African Journal Online, Bioline International, Open-J-Gate and Pharmacy Abstracts

\section{INTRODUCTION}

Gastric epithelium is often attacked by physical, chemical or microbiological agents acting from the gastric lumen. Among the numerous injurious luminal agents and irritants of both exogenous and endogenous origin, the stomach is a site of massive production and concentration of reactive oxygen species (ROS), far higher than other tissues or biological fluids [1-2]. ROS provoke severe changes at the cellular level leading to cell death because of their extreme reactivity. They attack essential cell constituents, leading to the formation of toxic compounds [3]. Both superoxide anion radical $\mathrm{O}_{2} \cdot$ and hydroxyl radical $(\cdot \mathrm{OH})$ are involved in tissue damage through initiation of lipid peroxidation and disruption of the interstitial matrix [4].

Since prehistoric civilizations, people have relied on flora for their prophylactic or curative properties, to uphold and renovate health, and 
flora are well-known as a central source of numerous biologically active compounds. In recent times, we have observed an upward interest in plants as an important source of new pharmaceuticals [5]. Delonix regia (Boj. Ex Hook.) Raf. (Fabaceae, sub family: Caesalpiniaceae) is commonly called as Gul mohor in Hindi [6]. Delonix regia is an umbrellashaped, medium-sized tree reaching up to 40 feet high and with large red-orange flowers (in April-May) grown in most tropical countries [7]. Stem bark of Delonix regia contains lupeol, epilupeol, $\beta$-sitosterol, stigmasterol and $p$ methoxybenzaldehyde [8]. It has folkloric reputation as diuretic, anthelmintic, leucorrhoea and astringent [8]. Also, Delonix regia is used to treat bruises, wounds, piles, gastric problems, body pain, and rheumatic pain of joints $[9,10]$.

On the basis of literature survey, the aim of the present study was to assess gastroprotective potential of ethanol extract from stem bark of Delonix regia (EDR) on ethanol and cold restrain stress-induced ulcer in experimental rats.

\section{EXPERIMENTAL}

\section{Collection of plant material}

The stem bark of Delonix regia was collected from the garden of the Bazikhera of Unnao district of Uttar Pradesh in the month of May to June 2011. Plant materials were taxonomically identified and authenticated by Dr Anamika Tripathi, Associate Professor, Hindu College, Moradabad as Delonix regia with registration no. $\mathrm{HC} / \mathrm{Bot} / \mathrm{PERL}-26$. The plant materials to be used were dried under the shade and were later ground to a fine powder. The powdered drug was extracted successively using soxhlet apparatus (Borosil, India) with various solvents in an increasing order of polarity viz., Petroleum ether, chloroform, ethyl acetate and ethanol. Yields for petroleum ether $\left(40-60{ }^{\circ} \mathrm{C}\right)$, chloroform, ethyl acetate and ethanol extracts were 0.76, 0.77, 0.80 and $1.63 \% \mathrm{w} / \mathrm{w}$, respectively. In initial pilot studies of stem bark, ethanol extract showed antiulcer activity.

\section{Preliminary phytochemical studies}

EDR obtained was subjected to preliminary qualitative tests for various plant constituents by chemical tests $[11,12]$.

\section{Experimental animals}

Wistar albino rats of either sex weighing 180 $220 \mathrm{~g}$ were used for all experiments. All animals were housed in polypropylene cages in an airconditioned area at $25 \pm 2^{\circ} \mathrm{C}$ with 12 :12-h light and dark cycle, respectively. They were given feed and water ad libitum. The optimum conditions for experiments were decided on the basis of initial pilot experiments. The Institutional Animal Ethics Committee affiliated to CPCSEA (837/ac/04/CPCSEA), India, approved the protocols used for animal experiments.

\section{Acute oral toxicity}

According to Organization for Economic Cooperation Development (OECD) guideline 423 [13], EDR at a dose level of 5, 50, 300 and 2000 $\mathrm{mg} / \mathrm{kg}$ [orally (p.o.)] was used for acute oral toxicity study. Three female rats, each sequentially dosed at intervals of $48 \mathrm{~h}$, were used for the test. Once-daily cage-side observations for changes in skin, fur, eyes, mucous membrane (nasal), autonomic nervous system (salivation, lacrimation, perspiration, piloerection, urinary incontinence and defaecation) and central nervous system (drowsiness, gait, tremors, and convulsions) changes were recorded. Mortality, if any, was determined over a period of 2 weeks.

\section{Selection of doses}

For the assessment of antiulcer activity by animal models, three dose levels of EDR were chosen in such a way that middle dose was approximately one-tenth of the maximum dose during acute toxicity studies, and a low dose, which was $50 \%$ of the one tenth dose, and a high dose, which was twice that of one-tenth dose $(100,200$ and $400 \mathrm{mg} / \mathrm{kg}$ ).

\section{Evaluation of ethanol-induced ulcers}

The antiulcerogenic activity of EDR was performed in ethanol induced ulcer model as described by Hollander et al [14]. In this study, $24 \mathrm{~h}$ fasted rats were randomly distributed into 5 groups as follows:

Group 1: Animals received normal saline and served as control.

Groups 2, 3 and 4: Animals received 100, 200 and $400 \mathrm{mg} / \mathrm{kg}$ body weight. of EDR, respectively.

Group 5: Animals received Lansoprazole (20 $\mathrm{mg} / \mathrm{kg}$ ) orally and served as the reference drug for comparison.

Gastric ulcers were induced by oral administration of $1 \mathrm{ml}$ of absolute ethanol per rat. Test substances were given $30 \mathrm{~min}$ before the ulcerative agent and after $1 \mathrm{~h}$ animals were 
sacrificed by cervical dislocation and stomach was incised along the greater curvature and examined for ulcers in the glandular region. Stomach of all treated and control rats were subjected to visual macroscopic examination and ulcer score was calculated as follows: $0=$ normal mucosa, 0.5 = blushing, $1=$ spot ulcers, $1.5=$ hemorrhage streaks, $2=3 \mathrm{~mm}<$ ulcers $<5 \mathrm{~mm}$ and $2.5=$ ulcers $>5 \mathrm{~mm}$. Finally, GSH, superoxide dismutase (SOD), catalase (CAT), myeloperoxidase (MPO), cytokines and nitric oxide (NO) levels in stomach tissue were measured and compared with that of control rat group.

\section{Evaluation of reduced glutathione (GSH) content}

All groups of rats treated were utilised to estimate the reduced glutathione (GSH) content in stomach tissues as non-protein sulfhydryls according to the method described by Sedlak and Lindsay [15]. Glandular segment from each stomach was homogenised in $5 \mathrm{ml}$ ice-cold 0.02 $\mathrm{M}$ EDTA solution $(0.02 \mathrm{M})$. Aliquots $(4 \mathrm{ml})$ of tissue homogenate were mixed with $3.2 \mathrm{ml}$ of distilled water and $0.8 \mathrm{ml}$ of $50 \%(\mathrm{w} / \mathrm{v})$ trichloroacetic acid (50\%) in glass tubes and centrifuged at $1000 \times \mathrm{g}$ for $15 \mathrm{~min}, 2 \mathrm{ml}$ supernatant were mixed with $4 \mathrm{ml}$ Tris buffer $(0.4$ $\mathrm{M}, \mathrm{pH}$ 8.9) and 5,5'-dithio-bis(2-nitrobenzoic acid) (DTNB; $0.01 \mathrm{M}$ ) was added. After shaking the reaction mixture, its absorbance was measured at $412 \mathrm{~nm}$ within $5 \mathrm{~min}$ of the addition of DTNB against blank with no homogenate.

\section{Superoxide dismutase activity (SOD) assay}

Superoxide dismutase activity was assayed spectrophotometrically as previously described by Misra and Fridovich [16]. This method is based on the capacity of SOD to inhibit the autoxidation of epinephrine to adrenochrome. The colour reaction was measured at $480 \mathrm{~nm}$. One unit of enzyme was defined as the amount of enzyme required to inhibit the rate of epinephrine autoxidation by $50 \%$ at $36^{\circ} \mathrm{C}$.

\section{Catalase activity assay (CAT)}

The stomach was homogenized in $50 \mathrm{mM}$ Tris$\mathrm{HCl}, \mathrm{pH} 7.5(1 / 10, \mathrm{w} / \mathrm{v})$ and centrifuged at $2400 \mathrm{~g}$ for $15 \mathrm{~min}$. The supernatant was assayed spectrophotometrically [17], which involve monitoring the degradation of $\mathrm{H}_{2} \mathrm{O}_{2}$ in the presence of cell homogenate at $240 \mathrm{~nm}$.
Assay of myeloperoxidase (MPO) in gastric tissue

Myeloperoxidase, an enzyme found primarily in neutrophil azurophilic granules, has been used extensively as a biochemical marker for granulocyte infiltration into various tissues, including the gastrointestinal tract $[18,19]$. MPO activity was determined using an MPO activity measurement kit by adding $0.2 \mathrm{ml}$ of $\mathrm{o}$ dianisidine hydrochloride and $0.0005 \%$ hydrogen peroxide to $4 \mathrm{ml}$ buffer containing 0.2 $\mathrm{ml}$ homogenates. MPO activity was assayed at room temperature by measuring the increase in absorbance at $460 \mathrm{~nm}$ due to the fluorescent product oxidized by the $\mathrm{H}_{2} \mathrm{O}_{2}$ generated redox intermediate. MPO activities were expressed as units per gram of tissue.

\section{Evaluation of cytokines in gastric tissue}

The cytokine levels of IL- 6 and TNF- $\alpha$ in gastric tissue were evaluated using ELISA kits according to the manufacturer's instructions (Minneapolis, USA). Supernatant of homogenates or cytokine standards $(100 \mu \mathrm{l})$ were respectively loaded into each well and then followed with biotin conjugated secondary antibodies. To obtain colour reaction, streptavidin-HRP and substrate solution were added. The absorbance was measured at $450 \mathrm{~nm}$. A standard curve was run on each assay plate using recombinant IL- 6 and TNF- $\alpha$ in serial dilution. The results were expressed $\mathrm{pg} / \mathrm{mg}$ tissue.

\section{Determination of NO level in gastric tissue}

The level of nitric oxide in the gastric tissue was evaluated as total nitrate/nitrite using Griess reagent [20] and the operational processes were measured in accordance with the NO kit instructions. Briefly, $50 \mu \mathrm{l}$ of tissue supernatant was added to $50 \mu \mathrm{l}$ Griess reagent $[0.1 \% \mathrm{~N}-(1$ naphthyl) ethylenediamine dihydrochloride, $1 \%$ sulphanilamide and $\left.2.5 \% \mathrm{H}_{3} \mathrm{PO}_{4}\right]$ and mixed. After incubation at room temperature for $10 \mathrm{~min}$, the absorbance was measured at $540 \mathrm{~nm}$. The results were expressed as $\mu \mathrm{mol} / \mathrm{g}$ protein.

\section{Assessment of cold restrain stress-induced ulcer}

Cold restrain stress in the $36 \mathrm{~h}$ fasted experimental rats, with free access to water, were administered normal saline $(1 \mathrm{ml} / 100 \mathrm{~g}$, p.o.), EDR (100, 200 and $400 \mathrm{mg} / \mathrm{kg}$, p.o.) or $\mathrm{PGE}_{2}$ (20 $\mathrm{mg} / \mathrm{kg}$ s.c.). One hour later after vehicle or EDR and 15 min after $P G E_{2}$, rats were immobilized by strapping the fore and hind limbs on a wooden plank and were kept at $4-6{ }^{\circ} \mathrm{C}$ for 4 
h [21]. Later, the animals were sacrificed by cervical dislocation. Stomachs were dissected out, opened along greater curvature and examined for ulcers. Ulcer index were calculated as per method described in previous ulcer model. Also, reduced glutathione (GSH) content in stomach tissues as non-protein sulfhydryls were estimated according to the method described by Sedlak and Lindsay [15].

\section{DPPH radical scavenging assay}

The radical scavenging activity of the EDR against 2,2-diphenyl-1-picryl hydrazyl (DPPH•) radical was determined [22]. Aliquots of the EDR of various concentrations $(10-100 \mu \mathrm{g} / \mathrm{ml})$ were prepared in methanol. One milliliter of these EDR concentrations was placed in test tubes and methanol $(3 \mathrm{ml})$ was added followed by $1 \mathrm{mM}$ methanol solution of DPPH $(0.5 \mathrm{ml})$. A blank solution containing the same amount of methanol and DPPH • was also prepared. After $30 \mathrm{~min}$ incubation at room temperature, the absorbance was read against blank at $517 \mathrm{~nm}$. Inhibition (\%) of free radical by DPPH• in percent (\%) was calculated using following formula:

Inhibition of DPPH• $(\%)=(1-\mathrm{Aa} / \mathrm{Ab}) 100$

where $A b$ is the absorption of the blank sample and $\mathrm{Aa}$ is the absorption of the extract. $\mathrm{IC}_{50}$ values, which represented the EDR concentration providing $50 \%$ inhibition of DPPH• radicals, were calculated from the plot of inhibition percentage against EDR concentration.

\section{Statistical analysis}

The results were expressed as mean \pm SEM and were analyzed using one-way analysis of variance followed by Dunnett's test using GraphPad Prism 5.0 (Graph-Pad Software Inc, San Diego, California, USA). $P<0.05$ was considered statistically significant.

\section{RESULTS}

\section{Phytochemical profile}

On the basis of preliminary phytochemical analysis of ethanol extract of stem bark of Delonix regia the results revealed the presence of glycosides, flavonoids, phenols and tannins.

\section{Acute oral toxicity}

In the present study, EDR had no effect on mortality, clinical signs, body weight change or gross observation in rats. Therefore, no acute toxicity was found in rats treated with EDR and $\mathrm{LD}_{50}$ might be higher than $2000 \mathrm{mg} / \mathrm{kg}$.

\section{Ethanol induced ulcers}

The antiulcerogenic effects of EDR on ethanol induced ulcer model in rats are shown in Table 1. Oral administration of ethanol produced severe ulcer index in the untreated animals. However, pretreatment with EDR decreased the ulceration in a dose dependent manner. At a dose of 400 $\mathrm{mg} / \mathrm{kg}$, the extract significantly $(p<0.001)$ reduced the intensity of gastric mucosal damage and the gastroprotective activity $(76.00 \%)$ was comparable to that of lansoprazole $(80.67 \%)$.

Table 1: Effect of EDR on ethanol induced ulcers in rats

\begin{tabular}{lcc}
\hline Treatment & Ulcer Index & $\begin{array}{c}\text { Protection } \\
(\%)\end{array}$ \\
\hline Control & $16.17 \pm 1.40$ & - \\
EDR 100 & $4.83 \pm 0.67^{\star * *}$ & 61.33 \\
EDR 200 & $3.50 \pm 0.82^{* * *}$ & 72.00 \\
EDR 400 & $3.00 \pm 0.39^{\star * *}$ & 76.00 \\
Lansoprazole & $2.42 \pm 0.24^{\star * *}$ & 80.67 \\
\hline Values are expressed as mean \pm SEM $(n=6)$. \\
ANOVA followed by Dunnett's test with control group. \\
Significance represented as ${ }^{* * *}(p<0.001)$
\end{tabular}

\section{Effect on GSH, SOD and CAT level}

EDR replenished the GSH level in all doses and it was significant $(p<0.001)$ in doses of 200 and $400 \mathrm{mg} / \mathrm{kg}$. In the control group the SOD activity was $0.12 \pm 0.11(\mathrm{U} / \mathrm{mg}$ protein). SOD activities in treatment with different doses of EDR and reference were comparable and statistically significant. The dose dependent antioxidant activity of EDR has been suggested to play a role in the relief of long-term complications and the oxidative stress. CAT were $90 \pm 12$ ( $\mu \mathrm{moleH}_{2} \mathrm{O}_{2} / \mathrm{mg}$ of protein/minute) in control group rats while it was increased significantly ( $p$ $<0.001$ ) in rats pre-treated with EDR (200 and $400 \mathrm{mg} / \mathrm{kg}$ ) (Table 2).

\section{Effect on MPO, IL-6, TNF- $\alpha$ and NO level}

The levels of MPO in gastric tissue were decreased and it was statistically significant in all doses of EDR $(p<0.001)$. The level of TNF- $\alpha$ were decreased significantly $(p<0.001)$ in group of rats pre-treated with EDR comparable to standard drug Lansoprazole (Fig 1). 
Table 2: Effect of EDR on SOD, CAT and GSH in ethanol induced ulcer

\begin{tabular}{|c|c|c|c|}
\hline Treatment & $\begin{array}{c}\text { SOD } \\
\text { (U/mg protein) }\end{array}$ & $\begin{array}{c}\text { CAT activity } \\
\text { ( } \mathrm{mmoleH}_{2} \mathrm{O}_{2} / \mathrm{mg} \text { of } \\
\text { protein } / \mathrm{minute})\end{array}$ & $\begin{array}{c}\text { GSH } \\
(\mu \mathrm{g} / \mathrm{mg} \text { protein) }\end{array}$ \\
\hline Control & $0.12 \pm 0.01$ & $90 \pm 12$ & $0.89 \pm 0.05$ \\
\hline EDR 100 & $0.21 \pm 0.03$ & $200 \pm 30^{* *}$ & $1.17 \pm 0.07^{*}$ \\
\hline EDR 200 & $0.24 \pm 0.02^{*}$ & $250 \pm 26^{\star * *}$ & $1.52 \pm 0.6^{\star *}$ \\
\hline EDR 400 & $0.27 \pm 0.02^{*}$ & $270 \pm 32^{\star \star *}$ & $1.63 \pm 0.09^{\star \star *}$ \\
\hline Lansoprazole & $0.28 \pm 0.05^{\star *}$ & $300 \pm 40^{* * *}$ & $1.70 \pm 0.08^{\star * *}$ \\
\hline
\end{tabular}

The EDR decreased the level of IL-6 in all groups of rats pre-treated with EDR and it were statistically significant $(p<0.01)$ at $100 \mathrm{mg} / \mathrm{kg}$ and $(p<0.001)$ at remaining dose level. NO level in gastric tissue was also significantly decreased $(p<0.001)$ in doses of EDR (200 and 400 $\mathrm{mg} / \mathrm{kg}$ ) and comparable to Lansoprazole (Fig 2).

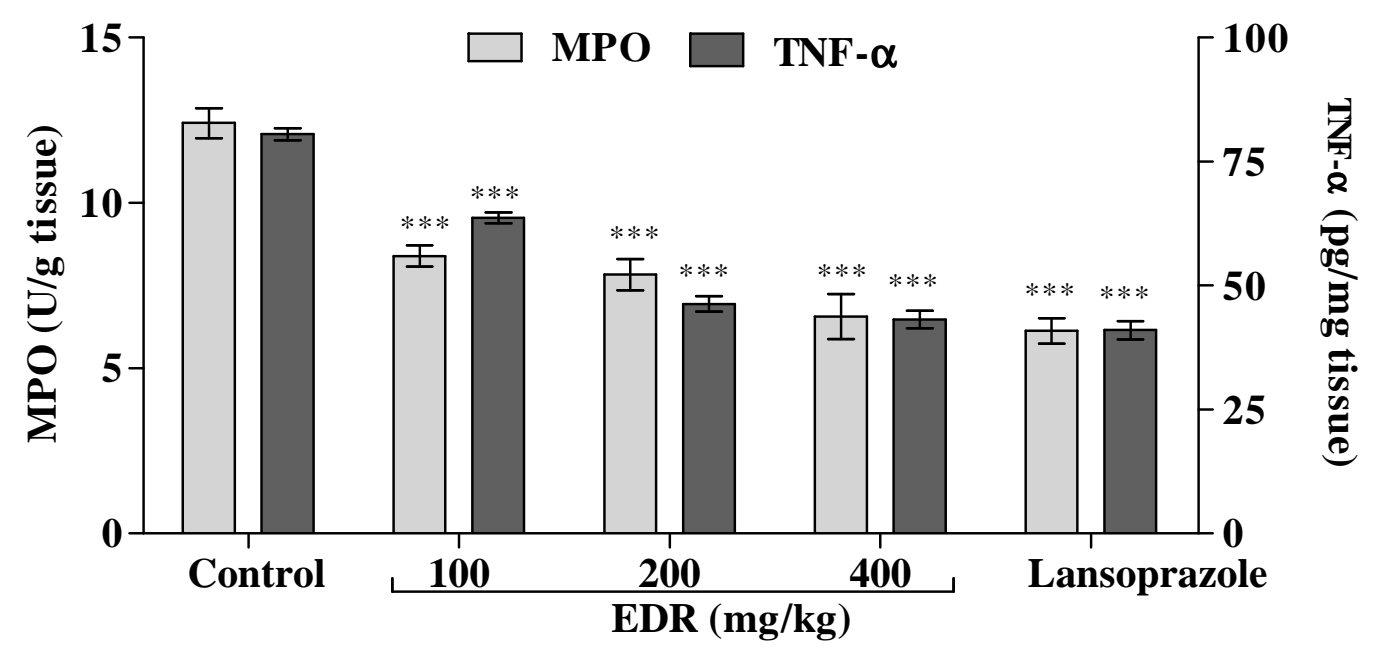

Fig. 1: Effect of EDR on the level of MPO and TNF- $\alpha$ in gastric tissue of ethanol induced ulcer in rats. Bars are expressed as means \pm SEM $(n=6)$. Analysis of variance followed by Dunnett's test with control group; ${ }^{* * *} p<$ 0.001 were considered significant

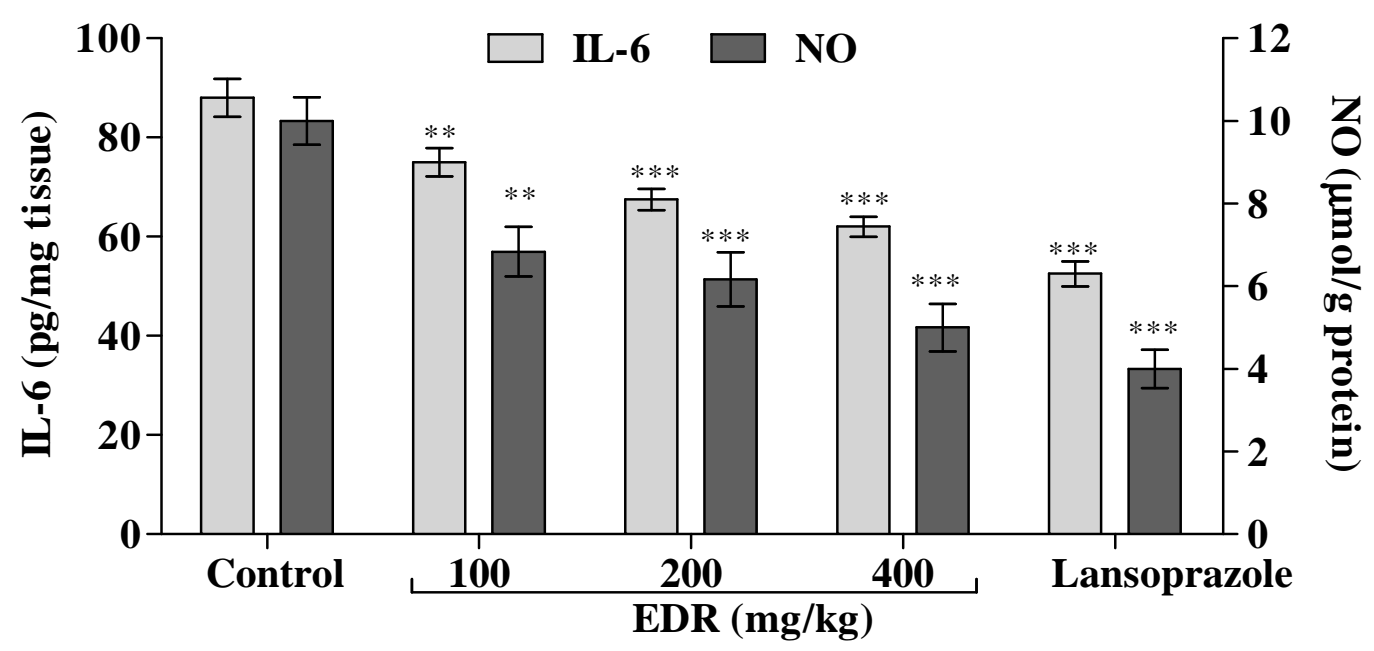

Fig. 2: Effect of EDR on the level of IL-6 and NO in gastric tissue of ethanol induced ulcer in rats. Bars are expressed as means \pm SEM $(n=6)$. Analysis of variance followed by Dunnett's test with control group; ${ }^{* *} p<0.01$ and ${ }^{* * *} p<0.001$ were considered significant 
Table 3: Effect of EDR on ulcer index and GSH level Cold restrain stress-induced ulcers in rats

\begin{tabular}{lccc}
\hline Treatment & Ulcer Index & Protection $(\%)$ & GSH $(\boldsymbol{\mu g} / \mathbf{g}$ tissue $)$ \\
\hline Control & $11.83 \pm 1.99$ & - & $130.5 \pm 17.4$ \\
EDR 100 & $6.23 \pm 0.97^{*}$ & 47.34 & $157 \pm 12.4$ \\
EDR 200 & $4.65 \pm 1.12^{* * *}$ & 60.69 & $191 \pm 10.56^{*}$ \\
EDR 400 & $1.86 \pm 1.02^{\star * *}$ & 84.28 & $213 \pm 11.8^{\star * *}$ \\
PGE $_{2}$ & $1.48 \pm 1.36^{\star * *}$ & 87.49 & $205.4 \pm 12.3^{\star *}$ \\
\hline
\end{tabular}

Values are expressed as mean \pm SEM $(n=6)$. ANOVA followed by Dunnett's test with control group. Significance represented as * $(p<0.05),{ }^{* *}(p<0.01)$ and ${ }^{* * *}(p<0.001)$

\section{Cold restrain stress-induced ulcer}

As observed in Table 3, ulcerated regions in the gastric body after $4 \mathrm{~h}$ of cold restrain-stress was observed in normal saline treated animals with ulcer index of $11.83 \pm 1.99$. EDR at doses of 100 , 200 and $400 \mathrm{mg} / \mathrm{kg}$ significantly reduced ulcer index by $47.34 \%(p<0.05), 60.69 \%(p<0.001)$ and $84.28 \%(p<0.001)$ respectively. $\mathrm{PGE}_{2}(20$ $\mathrm{mg} / \mathrm{kg}$; s.c.) administration also prevented the ulcer injury $(p<0.001)$. The GSH level were replenished by both EDR (200 and $400 \mathrm{mg} / \mathrm{kg}$ ) and $\mathrm{PGE}_{2}$ but EDR at dose $100 \mathrm{mg} / \mathrm{kg}$ was unable to do so.

\section{Effect of EDR on anti-oxidant assay}

EDR exhibited strong antioxidant activity in the DPPH inhibition assay as evidenced by the low $I_{50}$ value, $45.23 \pm 3.23 \mu \mathrm{g} / \mathrm{ml}$, were comparable to ascorbic acid's $\mathrm{IC}_{50}$ value, $41.54 \pm 2.92 \mu \mathrm{g} / \mathrm{ml}$.

\section{DISCUSSION}

Ethanol induced gastric ulcers are believed to arise as a result of stasis in gastric blood flow, which contributes to the development of the hemorrhagic and necrotic aspects of tissue injury [23]. Occurrence of these ulcers, which is predominant in the glandular part of the stomach, was reported to stimulate the formation of reactive oxygen species [24], resulting in damage to rat gastric mucosa [25]. The obtained results suggest that the EDR, exhibiting strong antioxidant and radical scavenging potential, has remarkably restricted ethanol-induced ulceration. Neutrophil infiltration plays a very important role in the progression of injury and inflammation by aggregation and release of tissue-disrupting substance in various tissues, plus gastric mucosal lesions [26,27]. Prior study has established that neutrophil infiltration into gastric mucosal tissues is involved in the progress of acute gastric mucosal lesions [28]. The accumulation of neutrophil infiltration into the gastric mucosal tissues is estimated by MPO [29]. Furthermore, a reduction in the activity of MPO can be interpreted as a manifestation of the anti-inflammatory activity. In this study, neutrophil infiltration in the gastric mucosa was evidenced from the increased MPO activity in the ulcer control group, and pre-treatment of EDR showed a notable inhibition on the accumulation of MPO, revealing that EDR may possess gastroprotective properties through alleviating gastric mucosal inflammation.

Ethanol ingestion may activate the innate immune system leading to the release of the proinflammatory cytokines, such as TNF- $\alpha$ and IL-6 [30]. Previous findings implicate that the levels of IL-6 and TNF- $\alpha$ remarkably increased in the gastric tissue of ethanol-induced ulcer [31,32]. TNF- $\alpha$, a representative inflammatory cytokine with pleiotropic functions, plays a key role in the process of inflammation. It is well known that TNF- $\alpha$ has disadvantageous effects, such as inducing tissue injury, inflammations as well as bacterial and viral infections. Thus, we believe that the inflammatory process, which happens as a part of the body's natural defense against tissue damage, is generally associated with an increase in oxidative stress. This stress generates the reactive oxygen species and produces the lipid peroxidation which increases the MPO activity. The results of this study represent direct evidence that the EDR has a marked antiinflammatory effects. These properties are achieved by a decrease in proinflammatory mediators, including myeloperoxidase, IL- 6 and TNF- $\alpha$, and a reduction in leukocyte activation $[33,34]$.

Stress is associated with inactivation of mucosal prostaglandin syntheses by accumulating hydrogen peroxide, an endogenous pathway of prostaglandin synthesis inhibition, which also causes reactive oxygen species (ROS) generation [35]. It is well known that ROS deplete NP-SH levels in the gastric mucosa $[3,36]$. It is also interesting to note that EDR was able to significantly prevent depletion of NP-SH levels in the gastric mucosa compared to control rats, thus confirming the gastroprotective mechanism of EDR to be partly modulated by NP-SH replenishment. 
The preliminary phytochemical screening of EDR revealed the presence of glycosides flavonoids, phenols and tannins. Previous studies have shown these compounds may be related to their free-radical scavenging and antioxidant properties and play a major role in the mechanism of gastroprotection [37]. It is, therefore, possible that the gastroprotective effects observed with the EDR may be attributable to its phytochemical constituents (secondary metabolites) and strong antioxidant activity.

\section{CONCLUSION}

The present results revealed that ethanol extract of Delonix regia protects gastric mucosa from acute gastric mucosal injury probably by its potent antioxidant action. Delonix regia warrants additional attention because it could represent a new interesting pharmacological tool for the treatment of acute erosive gastropathy.

\section{ACKNOWLEDGEMENT}

The authors express their sincere thanks to Prof. RM Dubey, Vice Chancellor, IFTM University, Moradabad, Uttar Pradesh, India, for providing research facilities in the laboratories of the University and his constant encouragement to carry out the research work. This work is a part of $\mathrm{PhD}$ research work of IFTM University.

\section{REFERENCES}

1. Graziani G, D'Argenio G, Tuccillo $C$, Loguercio $C$, Ritieni $A$, Morisco $F$, Blanco $C D V$, Fogliano $V$, Romano $M$. Apple polyphenol extracts prevent damage to human gastric epithelial cells in vitro and to rat gastric mucosa in vivo. Gut 2005; 54: 193-200.

2. Alvarez-Suarez JM, Dekanski D, Ristic S, Radonjic NV, Petronijevic ND, Giampieri F, Astolfi P, GonzálezParamás AM, Santos-Buelga C, Tulipani S, Quiles JL, Mezzetti B, Battino M. Strawberry polyphenols attenuate ethanol-induced gastric lesions in rats by activation of antioxidant enzymes and attenuation of MDA increase. PLoS One 2011; 6(10): e25878.

3. Kahramam A, Erkasap N, Koken T, Serteser M, Aktepe $F$, Erkasap S. The antioxidant and antihistaminic properties of quercetin in ethanol-induced gastric lesions. Toxicol 2003; 183: 133-142.

4. Ineu RP, Oliveira CS, Oliveira VA, Moraes-Silva L, Almeida da Luz SC, Pereira ME. Antioxidant effect of zinc chloride against ethanol-induced gastrointestinal lesions in rats. Food Chem Toxicol 2013; 58: 522529.

5. Zanatta F, Gandolfi RB, Lemos M, Ticona JC, Gimenez $A$, Clasen BK, Filho VC, Andrade SF.
Gastroprotective activity of alkaloid extract and 2phenylquinoline obtained from the bark of Galipea longiflora Krause (Rutaceae). Chem-Biol Interact 2009; 180(2): 312-317.

6. Shanmukha I, Patel H, Patel J. Riyazunnisa. Quantification of total phenol and flavonoid content of Delonix regia flowers. Int J ChemTech Res 2011; 3: 280-283.

7. Jungalwala FB, Cama HR. Carotenoids in Delonix regia (Gul Mohr) Flower. Biochem J 1962; 85: 1-8.

8. Jahan I, Rahman MS, Rahman MZ, Kaisar MA, Islam MS, Wahab A, Rashid MA. Chemical and biological investigations of Delonix regia (Bojer ex Hook.) Raf. Acta Pharm 2010; 60: 207-215.

9. Ray S, Sheikh M, Mishra S. Ethnomedicinal plants used by tribals of East Nimar region, Madhya Pradesh. IJTK 2011; 10: 367-371.

10. Shewale VD, Deshmukh TA, Patil LS, Patil VR. Antiinflammatory activity of Delonix regia (Boj. Ex. Hook). Adv Pharmacol Sci 2012; 2012: 1-4.

11. Khandelwal KR. Practical Pharmacognosy Techniques and Experiments. Pune: Nirali Prakashan; 2011.

12. Trease GE, Evans WC. A Text Book of Pharmacognosy. Oxford, UK: ELSB Baillere Tindal; 1987.

13. OECD. Acute oral toxicity. Acute oral toxic class method guideline 423 adopted 17.12.2001. In, Eleventh Addendum to the, OECD, guidelines for the testing of chemicals, organization for economic co-operation and development, Paris; 2001.

14. Hollander D, Taranawski A, Krause WJ, Gergely $H$. Protective effect of sucralfate against alcohol-induced gastric mucosal injury in the rat. Gastroenterol 1985; 88: 366-374.

15. Sedlak J, Lindsay RH. Estimation of total, proteinbound, and nonprotein sulfhydryl groups in tissue with Ellman's reagent. Anal Biochem 1968; 25: 192-205.

16. Misra HP, Fridovich I. The role of superoxide anion in the autoxidation of epinephrine and a simple assay for superoxide dismutase. J Biol Chem 1972; 247(10): 3170-3175.

17. Aebi H. Catalase in vitro. Methods Enzymol 1984; 105: 121-126.

18. Costa NRD, Silva RO, Nicolau $L A D$, Lucetti $L T$, Santana APM, Aragao KS, Soares PMG, Ribeiro RA, Souza MHLP., Barbosa ALR, Medeiros JR. Role of soluble guanylate cyclase activation in the gastroprotective effect of the HO-1/CO pathway against alendronateinduced gastric damage in rats. Eur $J$ Pharmacol 2013; 700: 51-59.

19. Krawisz JE, Sharon P, Stenson WF. Quantitative assay for acute intestinal inflammation based on myeloperoxidase activity. Assessment of inflammation in rat and hamster models. Gastroenterol 1984; 87: 1344-1350.

20. Green LC, Wagner DA, Glogowski J, Skipper PL, Wishnok JS, Tannenbaum SR. Analysis of nitrate, nitrite, and [15N]nitrate in biological fluids. Anal Biochem 1982; 126: 131-138.

Trop J Pharm Res, June 2015; 14(6): 1069 
21. Sairam K, Priyambada S, Aryya NC, Goel RK. Gastroduodenal ulcer protective activity of Asparagus racemosus, an experimental, biochemical and histological study. J Ethnopharmacol 2003; 86; 1-10.

22. Ayoola GA, Coker HAB, Adesegun SA, Adepoju-Bello A, Obaweya K, Ezennia EC, Atangbayila TO. Phytochemical screening and antioxidant activities of some selected medicinal plants used for malaria therapy in southwestern Nigeria. Trop J Pharm Res 2008; 7: 1019-1024.

23. Guth PH, Paulsen G, Nagata H. Histologic and microcirculatory changes in alcohol-induced gastric lesions in the rat, effect of prostaglandin cytoprotetion. Gastroenterol 1984; 87(5): 1083-1090.

24. Mizui $T$, Sato $H$, Hirose $F$, Doteuchi M. Effect of antiperoxidative drugs on gastric damage induced by ethanol in rats. Life Sci 1987; 41: 755-763.

25. Peskar BM, Lange K, Hoppe U, Peskar BA. Ethanol stimulates formation of leukotriene $C 4$ in rat gastric mucosa. Prostaglandins 1986; 31: 283-293.

26. Kobayashi T, Ohta Y, Yoshino J, Nakazawa S. Teprenone promotes the healing of acetic acidinduced chronic gastric ulcers in rats by inhibiting neutrophil infiltration and lipid peroxidation in ulcerated gastric tissues. Pharmacol Res 2001; 43 : 23-30.

27. Wallace JL, Keenan CM, Granger DN. Gastric ulceration induced by nonsteroidal antiinflammatory drugs is a neutrophil-dependent process. Am J Physiol Gastrointest Liver Physiol 1990; 259: G462-467.

28. Nishida $K$, Ohta $Y$, Ishiguro I. Contribution of NO synthases to neutrophil infiltration in the gastric mucosal lesions in rats with water immersion restraint stress. FEBS Lett 1998 425: 243-248.

29. Takeuchi K, Yasuhiro T, Asada Y, Sugawa Y. Role of nitric oxide in pathogenesis of aspirin-induced gastric mucosal damage in rats. Digestion 1998; 59: 298307.

30. Salga MS, Ali HM, Abdulla MA, Abdelwahab SI. Gastroprotective activity and mechanism of novel
dichlorido-zinc(II)-4-(2-(5-methoxybenzylideneamino) ethyl)piperazin-1-iumphenolate complex on ethanolinduced gastric ulceration. Chem-Biol Interact 2012; 195: 144-153.

31. Mei X, Xu D, Xu S, Zheng $Y, X u S$. Novel role of Zn (II)curcumin in enhancing cell proliferation and adjusting proinflammatory cytokine-mediated oxidative damage of ethanol-induced acute gastric ulcers. Chem-Biol Interact 2012; 197: 31-39.

32. Rodrigues e Silva $A A$, Marques $B M$, Vasconcelos $C H$, de Paulo TPV, de Souza FE, Vieira MA, Araújo EB, Rios LC, Leite ACR, Maia MBS. Protective effect of Chresta martii extract on ethanol-induced gastropathy depends on alpha-2 adrenoceptors path- ways but not on nitric oxide, prostaglandins or opioids. J Ethnopharmacol 2012; 142: 206-212.

33. Beninca JP, Dalmarco JB, Pizzolatti MG, Frode TS. Analysis of the antiinflammatory properties of Rosmarinus officinalis L. in mice. Food Chem 2011; 124: 468-475.

34. Reuter S, Gupta S, Chaturvedi MM, Aggarwal BB. Oxidative stress, inflammation, and cancer, how are they linked? Free Radic Biol Med 2010; 49: 16031616.

35. Bandyopadhyay D, Biswas K, Bhattacharyya M, Reiter RJ, Banerjee RK. Involvement of reactive oxygen species in gastric ulceration, protection by melatonin. Indian J Exp Biol 2002; 40: 693-705.

36. Nagy L, Nagata $M$, Szabo S. Protein and non-protein sulfhydryls and disulfides in gastric mucosa and liver after gastrotoxic chemicals and sucralfate, possible new targets of pharmacologic agents. World $\mathrm{J}$ Gastroenterol 2007; 13: 2053-2060.

37. Al-Rejaie SS, Abuohashish HM, Ahmed MM, Aleisa AM, and Alkhamees $O$. Possible biochemical effects following inhibition of ethanol-induced gastric mucosa damage by Gymnema sylvestre in male Wistar albino rats. Pharm Biol 2012; 50(12): 1542-1550. 